\title{
REFLEXÕES SOBRE AS POLÍTICAS PÚBLICAS NA ÁREA DE FORMAÇÃO CONTINUADA DE PROFESSORES: A EXPERIÊNCIA DO MUNICÍPIO DE CANOAS/RS
}

\section{Evaldo Luis Pauly \\ Centro Universitário La Salle \\ (UNILASALLE)}

Cardoso Leffa Romi

Programa de Pós-Graduação em Educação do

Centro Universitário La Salle

\section{Dirléia Fanfa Sarmento}

Programa de Pós-Graduação em Educação do

Centro Universitário La Salle

\section{Resumo}

Este artigo desenvolve uma reflexão pedagógica sobre uma experiência de formação continuada de professores. Essa reflexão inicia com uma polêmica acerca do valor econômico da boa educação, propondo tal valor como um dos critérios capazes de fundamentar a avaliação sobre a formação continuada de professores. A terceira e última parte, apresenta e avalia a experiência do programa de formação continuada de professores "Escola em Movimento: Saberes e Fazeres em Cena". O programa desenvolveu-se no contexto do projeto de pesquisa "Alfabetização nos Anos Iniciais do Ensino Fundamental e formação de professores na Rede Municipal de Ensino de Canoas: a pesquisa-ação colaborativa como elemento de qualificação das práticas educativas" desenvolvido pelo Observatório da Educação do Centro Universitário La Salle, com apoio da Coordenação de Aperfeiçoamento de Pessoal de Nível Superior (Capes) e do Instituto Nacional de Estudos e Pesquisas Educacionais Anísio Teixeira (Inep).

Palavras-chave: Formação continuada de professores; Canoas/RS, Observatório da Educação.

Olh@res, Guarulhos, v. 2, n. 1, p. 270-301. Maio, 2014. 


\title{
ACCOUNT FOR PUBLIC POLICIES IN THE AREA OF CONTINUING TEACHERS EDUCATION: THE EXPERIENCE OF THE CITY OF CANOAS/RS
}

\begin{abstract}
This article develops a pedagogical account for an experience of continuing teachers education. This reflection begins with a polemic on the economic value of good education, proposing that value as one criterion able to support the assessment of the continuing teachers education. The third and last section presents and evaluates the experience of the Continuing Teachers Education Program "School on the Move: Knowledge and Doings on Stage". The program was developed in the context of the research project "Alphabetization in the early years of elementary school and teacher education in public schools in Canoas: collaborative action research as part of qualifying educational practices" developed by the Education Observatory's La Salle University Center, with support from the Coordination for the Improvement of Higher Education Personnel (Capes), the Anísio Teixeira National Institute for Educational Studies and Research (Inep).
\end{abstract}

Keywords: continuous training of teachers; Canoas / RS; Education Observatory.

Olh@res, Guarulhos, v. 2, n. 1, p. 270-301. Maio, 2014. 


\section{A formação continuada de professores}

A UNESCO produziu um perfil do Magistério brasileiro com base nos “questionários respondidos por 5.000 docentes de escolas públicas e privadas das 27 Unidades da Federação" (UNESCO, 2004, p. 17). Na interpretação da UNESCO, embora os discursos aparentem o contrário, "grande parte dos docentes reflete, de modo geral, o imaginário da sociedade brasileira, contemporizando e minimizando situações de exclusão e desigualdades e reproduzindo nas suas práticas situações de violência simbólica”, portanto, a maioria do professorado não estaria em condições de "ultrapassar o senso comum" (UNESCO, 2004, p. 171). Ou seja, a maioria dos professores parece reproduzir o pensamento hegemônico entre a população. Vitor Henrique Paro, por sua vez, também sugere haver uma identificação entre o senso comum da maioria do Magistério com o pensamento comum do povo. Assim, os programas de formação continuada de professores necessitam propor uma mudança radical na compreensão da própria Educação, pois parcela do Magistério precisa superar o senso comum de que professor é um "simples provedor dos conhecimentos e informações" (2008, p. 21) pela concepção científica de que "a educação consiste na apropriação da cultura" (2008, p. 23), como patrimônio cultural da humanidade por todas as pessoas.

O senso comum popular exige que cientistas tenham muito conhecimento. No entanto, essa mesma concepção popular de ciência, exclui do rol dos cientistas os professores da Educação Infantil e dos anos iniciais. Desse modo, o senso comum do povo contribui para a perpetuação da pobreza ao disseminar a ilusão ideológica de que crianças e adolescentes matriculados nas escolas mantidas pela iniciativa estatal não carecem de sólida formação científica. Ao senso comum, basta que estes docentes cuidem das crianças oriundas das classes trabalhadoras. Para superar o senso comum do povo e, inclusive, de parcela do Magistério, parece conveniente reler os artigos 61 a 67 da $\operatorname{LDB}^{1}$, alterados pela Lei $\mathrm{n}^{\circ}$ 12.014/2009. Educação é assunto científico, responsabilidade técnica de pessoas habilitadas como cientistas da educação que são os docentes da Educação Básica, os do ensino superior e os pesquisadores da Área da Educação (LDB, art. 61, § único,

\footnotetext{
${ }^{1}$ Veja a Lei no 9.394/1996 e a legislação correlata em: http://www.planalto.gov.br/ccivil_03/leis/L9394.htm

Olh@res, Guarulhos, v. 2, n. 1, p. 270-301. Maio, 2014.
} 
I). Por outro lado, a educação universal e obrigatória é "direito público subjetivo" (art. 5), portanto, assunto de responsabilidade moral de qualquer um.

Numa avaliação político-eleitoral, o senso comum popular nutre a falsa crença de muitos eleitores de que qualquer pessoa pode educar, basta que goste e cuide da criança. Esse senso comum de parcela significativa do eleitorado contagia os legisladores que não sofrem constrangimentos eleitorais por votarem leis e matérias na área científica da educação sem nenhum controle técnico das organizações científicas da educação. Um exemplo deste fenômeno é a lenta tramitação, no Congresso Nacional, do Projeto de Lei $8035^{2}$ com o Plano Nacional de Educação (PNE) 2011-2020 proposto pelo MEC, após a realização da Conferência Nacional de Educação (CONAE). A proposta do PNE faz referências à formação de professores. Uma delas vinculada à meta 1 que universaliza até 2016, a educação infantil para crianças de 4 a 5 anos, para até 2020, metade da população com até três anos de idade. Para atingir esta meta, a estratégia 1.6, ao mesmo tempo, representa um avanço pedagógico ao exigir que o ensino na PréEscola tenha base científica.

Durante a tramitação do novo PNE, imprensa, partidos e parlamentares centralizaram o debate nos 7 ou $10 \%$ do PIB que a meta 20 destinaria à educação. A meta 15 prevê que o corpo docente da educação básica tenha formação específica de nível superior na sua área. Os cursos de licenciatura, no entanto, estão à míngua e sendo fechados nas IES públicas e privadas por falta de alunos. As estratégias desta meta serão capazes de aumentar a matrícula nas licenciaturas? O aumento de alunos para as licenciaturas depende de condições objetivas capazes de transformar

a docência numa profissão atraente socialmente em razão da sensível melhoria salarial e das boas condições de trabalho, para ela serão atraídos muitos jovens dispostos a investir seus recursos, tempo e energias numa alta qualificação obtida em graduações de longa duração e em cursos de pós-graduação. Com um quadro de professores altamente qualificado e fortemente motivado trabalhando em tempo integral numa única escola, estaremos formando os tão decantados cidadãos conscientes, críticos, criativos, esclarecidos e tecnicamente competentes para ocupar os postos do fervilhante mercado de trabalho (...). Estaria criado, por esse caminho, o tão desejado círculo virtuoso do desenvolvimento. (SAVIANI, 2009, p. 154)

\footnotetext{
${ }^{2}$ http://www.camara.gov.br/proposicoesWeb/fichadetramitacao?idProposicao=490116
}

Olh@res, Guarulhos, v. 2, n. 1, p. 270-301. Maio, 2014. 
A meta 16 prevê que metade dos professores da educação básica titule-se como especialista ou mestre na sua área de atuação. Quais as condições objetivas pelas quais poderão obter esta titulação? Haverá bolsas? Haverá liberação de carga horária? No Rio Grande do Sul, conforme o IBGE, em 2009, atuavam 128.429 professores na Educação Básica. Neste estado existem diversos programas de pósgraduação em áreas do conhecimento vinculadas à Educação Básica. Os PPG’s gaúchos na área da Educação, conforme a Planilha Comparativa da Avaliação Trienal da CAPES triênio 2007-2009, titulavam em torno de 300 mestres em educação por ano. Quantas vagas serão destinadas aos docentes da Educação Básica nos processos de seleção dos Mestrados? Consulta do Banco de Dados Geocapes indicava que, em 2011, os 283 Programas de Pós-Graduação do Rio Grande do Sul titularam 3.738 mestres, 1.130 doutores e 241 mestres profissionais. Deste conjunto de cursos e titulados, agrupamos 19 Programas de Pós-Graduação ${ }^{3}$ que atenderiam à demanda por formação de professores da Educação Básica no estado, teríamos 102 Mestres e 26 doutores! É, portanto, impossível que o RS alcance a meta 16, mantida a atual realidade.

Outro desafio para a qualificação da Educação Básica é o Índice de Desenvolvimento da Educação Básica. O IDEB está transformando o senso comum sobre educação. Cada nova divulgação do IDEB pauta a imprensa. Os meios de comunicação criam e divulgam rankings das escolas, destacando o sucesso das privadas e o fracasso das públicas. A TV promove debates. Algumas matérias jornalísticas investigam porque determinadas escolas públicas estão entre as melhores do país. A divulgação irresponsável do IDEB, sem análise técnicopedagógica, serve mais para propaganda no mercado educacional do que para solidificar uma opinião pública favorável à resolução dos problemas educacionais. O IDEB é um dos indicadores necessários ao diagnóstico científico do desempenho de alunos, docentes, escolas, políticas educacionais e sistemas de ensino. O Programa para Avaliação Internacional de Alunos (PISA) produzido pela Organização para a Cooperação e Desenvolvimento Econômico (OCDE) permite comparações internacionais que identificam boas práticas de ensino, de

\footnotetext{
${ }^{3}$ Consultando a GEOCAPES em: http://geocapes.capes.gov.br/geocapesds/\# para o número de mestres e doutores egressos dos PPG's de Artes Cênicas e Visuais; Ciências do Movimento Humano; Ciências Sociais; Comunicação; Educação; Educação Ambiental; Educação em Ciências; Ensino de Física; Filosofia; Geografia; História; Inclusão Social e Acessibilidade; Informática na Educação; Letras; Lingüística Aplicada; Matemática; Música; Psicologia e Química.
}

Olh@res, Guarulhos, v. 2, n. 1, p. 270-301. Maio, 2014. 
aprendizagem e dificuldades a serem superadas a partir da análise das boas práticas. O IDEB está mais para benchmarking do que para ranking, usando uma linguagem estranha à educação. É um índice de larga escala para medir a distância entre a educação que o povo brasileiro, de fato, recebe e aquela que, de direito, merece receber. O risco da divulgação irresponsável do IDEB reforça a crença do senso comum de que educação pública estatal é ruim e a educação pública privada é boa.

\section{O valor econômico da boa educação}

O valor econômico da boa educação parece ser um critério objetivo capaz de fundamentar a viabilidade e a necessidade de o poder público oferecer e avaliar programas de formação continuada de professores, razão pela qual esse ponto antecede a apresentação do programa de formação continuada "Escola em Movimento: Saberes e Fazeres em Cena". Os economistas calculam que o aumento de anos de estudos corresponda aumentos salariais. É o efeito, por exemplo, produzido pela condicionante da frequência escolar das crianças e adolescentes das famílias beneficiárias do Programa Bolsa Família.

O efeito de longo prazo do Bolsa parece ser o de aumentar a matrícula dos participantes em cerca de $18 \%$. Assumindo que isso leva a um aumento de $18 \%$ nos anos de escolaridade implica um ganho de cerca de 1,5 anos para a população-alvo. Utilizando os dados da PNAD 2004, estima-se que um ano adicional de escolaridade aumenta os salários em $11 \%$, o que implica um aumento de 16-17\% dos salários entre o terço mais pobre da população, o que equivale a um aumento de cerca de $1,5 \%$ dos salários de toda a população (...), ou, talvez, cerca de $0,8 \%$ do PIB. (GLEWWE; KASSOUF, 2012, p. 509)

O senso comum do Magistério reconhece o valor da educação para o desenvolvimento. No caso do aumento na escolaridade induzida pelo Programa Bolsa Família, representa um aumento no PIB de 0,8\%. Este é um indicador do que representa o valor econômico da educação. Amplos setores empresariais vinculados aos setores econômicos mais modernos da economia capitalista reconhecem esse valor e, nesse sentido, são aliados do Magistério na luta política pela superação do senso comum sobre educação. Em 20/09/2012 a Confederação Nacional da Indústria (CNI) concluiu que a indústria precisará de 7,2 milhões de técnicos até 2015 conforme a pesquisa "Mapa do Trabalho Industrial 2012" do Serviço Nacional de Aprendizagem Industrial (SENAI). "Apenas 6,6\% dos brasileiros entre 15 e 19 anos estão em cursos de educação profissional. Na Alemanha, esse índice é de 53\%. Nossos jovens precisam ver a formação

Olh@res, Guarulhos, v. 2, n. 1, p. 270-301. Maio, 2014. 
profissional como uma excelente oportunidade para o mercado de trabalho", afirma o diretor de Educação e Tecnologia da CNI, Rafael Lucchesi. Os dados disponibilizados para o Rio Grande do Sul indicavam a demanda

\begin{abstract}
por 554,3 mil profissionais capacitados, o que corresponde a 7,7\% de todo o país.

Ocupações com maior demanda (nível técnico): técnicos de controle da produção; operadores de máquinas de usinagem Controle Numérico Computadorizado; técnicos em eletrônica; técnicos em eletricidade e eletrotécnica; operadores de equipamentos de acabamento de chapas e metais.

Ocupações com maior demanda (> 200 horas): trabalhadores da indústria de alimentos (cozinheiros industriais); preparadores e operadores de máquinas-ferramenta convencionais; padeiros, confeiteiros e afins; mecânicos de manutenção de máquinas industriais; operadores de instalações e máquinas de produtos plásticos, de borracha e parafinas. (SENAI, 2012, p. 12)
\end{abstract}

O SENAI só consegue formar um excelente cozinheiro industrial em 200 horas, se antes ele concluiu, no mínimo, uma boa Educação Básica: 7.200 horas de escola! A formação técnica pressupõe uma Educação Básica de qualidade que não é barata porque exige investimentos públicos e privados compatíveis com a escola da sociedade do conhecimento. É o que se depreende dos números revelados pelo IBGE com a PNAD de 2011, divulgada em setembro de 2012. Esses dados justificam a conveniência de o município articular seu desenvolvimento econômico a partir do sistema municipal de ensino. Entre a população trabalhadora, a PNAD indica a queda, em 2011, do percentual de "trabalhadores com o ensino fundamental incompleto de $31,8 \%$ para $25,5 \%$ ", no sentido contrário, o "percentual de trabalhadores com pelo menos o ensino superior completo aumentou de 11,3\% em 2009, para 12,5\% em 2011" (PNAD, 2012, p. 60). Das 6,7 milhões de pessoas desempregadas, mais da metade - 53,6\% - "não tinham completado o ensino médio" (PNAD, 2012, p. 66). Melhorar a educação não é uma demanda humanista ou uma utopia socialista das esquerdas. Alguns setores empresariais brasileiros precisam assalariar mão de obra qualificada a partir de uma boa Educação Básica. É irracional pensar a educação pública como uma política pública destinada aos pobres. É uma demanda política também de setores empresariais.

Olh@res, Guarulhos, v. 2, n. 1, p. 270-301. Maio, 2014. 
A empregabilidade gerada por boa educação garantiu em 2011, um "rendimento médio mensal real dos domicílios (...) estimado em R\$ 2.419,00” (PNAD, 2012, p. 73). O Brasil dos trabalhadores não é um país de pobres. Outro indicador nessa direção é o acesso à Internet:

Em 2011, 77,7 milhões de pessoas de 10 anos ou mais de idade declararam ter utilizado a Internet (...). Houve um crescimento de $14,7 \%$ desta população em relação a 2009 , o que significou um acréscimo de 9,9 milhões de pessoas. Os usuários da Internet correspondiam a 46,5\% da população de 10 anos ou mais de idade. (PNAD, 2012, p. 79)

Se 10 milhões de pessoas aprenderam a usar a Internet em um ano, como é possível que não aprendam bem a matemática e o português em nove anos de Ensino Fundamental? Em especial "o grupo de 15 a 17 anos alcançado 74,1\%, e o de 18 ou 19 anos, 71,8\%" (PNAD, 2012, p. 81). Se mais de 70\% dos jovens utilizam a Internet, por que as bibliotecas escolares estão vazias? Será falta de inteligência dos usuários ou pobreza do acervo? Em 2011, 36,5\% das residências brasileiras estavam equipadas com computador ligado a Internet. Um pouco maior era o índice de domicílios com carro: 40,9\%. O Brasil não é mais um país de pobres, nada - a não ser a pobreza do preconceito - justifica a pobreza de nossa política educacional.

A tese é polêmica, por isso precisa ser pensada cientificamente. A Ciência Política já pesquisa essa mudança no perfil do eleitorado brasileiro e, portanto, na composição dos governos eleitos. O debate é se o Brasil tornou-se um país de classe média ou se permanece um país rico com um povo pobre. Nas palavras de Moreira Franco, Ministro-chefe da Secretaria de Assuntos Estratégicos - SAE - da Presidência da República, na última década:

35 milhões de pessoas entraram na classe média - que passou de $38 \%$ da população, em
2002 , para 53\%, em 2012, somando hoje mais de 100 milhões de brasileiros. Nesse
período, o país desenvolveu e implementou um conjunto de programas sociais
reconhecidamente eficazes para reduzir a pobreza e promover a inclusão produtiva. A
questão que se coloca neste momento é se esse mesmo leque de programas permanecerá
sendo a melhor opção, agora que a extrema pobreza foi reduzida a menos da metade e a
classe média passou a representar mais da metade da população brasileira. (SAE, 2012, p.
7) Há uma disputa teórica sobre a definição de classe média, conceito típico da sociologia de Max Weber. Para a SAE a nova classe média é formada por pessoas que atendem a duas condições sociais: a) vivem em "famílias com renda per capita entre $\mathrm{R} \$ 291$ e $\mathrm{R} \$ 1.019$ por mês" e b) há pouca possibilidade de empobrecerem no futuro. Por óbvio, a SAE define como "classe alta" as "famílias com nível de renda per capita acima de R\$1.019 por mês" (SAE, 2012, p. 12).

Olh@res, Guarulhos, v. 2, n. 1, p. 270-301. Maio, 2014. 
Pelos dados da SAE e da CNI, a metade do povo é de classe média, os pobres são $30 \%$ e os ricos formariam os demais $20 \%$ do povo brasileiro. Se verdadeira esta estratificação social, então, a maioria dos alunos das escolas públicas é de classe média. Alunos pobres seriam minoritários, embora quase todos os pobres nelas estejam matriculados. Essa mudança no perfil econômico, na opinião da SAE, se deve a "quatro determinantes imediatos" que são a mudança demográfica na composição das famílias, que permite aumentar o valor da renda per capita sem aumento real dos salários. Uma segunda variável determinante seriam as políticas de "transferências públicas às famílias" (Programa Bolsa Família, Benefício de Prestação Continuada e Previdência Rural). A terceira é o "maior acesso ao trabalho" e a quarta seriam os "ganhos de produtividade" dos trabalhadores. O ganho em produtividade teria sido o "determinante imediato mais importante para o aumento da renda da classe média brasileira" (SAE, 2012, p. 27-28). No chão de fábrica, ganho em produtividade significa que o trabalhador aprendeu a trabalhar melhor porque está mais educado, aprendeu a aprender na escola. Por pior diagnóstico que se faça da escola pública, ela foi capaz de melhorar a educação dos trabalhadores na última década, pois os "grupos que têm até a educação média representam mais de $90 \%$ da classe média” (SAE, 2012, p. 24).

A consciência política da nova classe média ainda não percebe que sua ascensão social foi, em boa medida, produto de sua melhor educação. Ela não percebe com a mesma clareza da classe alta, o valor da educação como promotora legítima e democrática das condições cognitivas necessárias para o indivíduo apropriar-se privadamente da riqueza econômica dela advinda. Para a SAE, essa é uma contradição ideológica da nova classe média:

Ao perceber ganhos privados associados à educação mais limitados
que os percebidos pela classe alta, a classe média pode estar
informando que conexões sociais na sociedade brasileira ainda
permanecem necessárias para que os ganhos dos investimentos em
educação se integralizem. Estudar medicina ou advocacia pode
continuar tendo mais valor para filhos de médicos ou advogados do
que para filhos de pais com baixa escolaridade. (SAE, 2012, p. 42)

IBOPE, CNI e SAE seguem a análise weberiana: o problema da classe média está na sua vacilação ideológica entre identificar-se com os regimes aristocráticos baseados nas relações pessoais ou com a meritocracia impessoal dos regimes democráticos. A classe média titubeia entre empenhar-se para obter reconhecimento social através da amizade e compadrio, ou por empenhar-se para

Olh@res, Guarulhos, v. 2, n. 1, p. 270-301. Maio, 2014. 
obter excelente desempenho escolar. Se quisermos interpretar essa contradição ideológica pela concepção marxista, a burguesia tem interesse em apropriar-se do ganho em produtividade - a mais valia - decorrente da melhor escolarização do proletariado, mesmo que implique em aumento salarial dos indivíduos. O embate ideológico entre o modelo de vida aristocrático e o democrático parece constituir o núcleo ideológico duro que o projeto político-pedagógico da escola pública estatal precisa derrotar política e pedagogicamente.

Os eleitores da nova classe média ainda não se percebem capazes e muito menos se sentem no legítimo direito democrático de se apropriarem privadamente do ganho econômico provocado pela boa escola mantida pelo poder público. Essa autodesvalia da nova classe média parece contagiar a escola e o magistério públicos. O valor econômico da educação do qual a nova classe média precisa apropriar-se privadamente foi calculado por técnicos do IPEA com "base na análise de multiplicadores de uma Matriz de Contabilidade Social - (...) - uma matriz quadrada que congrega todos os fluxos de renda e gasto da economia em um determinado ano de referência" (IPEA, 2011, p. 7). Sua conclusão: se o governo

gastar $\mathrm{R} \$ 1,00$ em educação pública, o PIB aumentará em $\mathrm{R} \$ 1,85$, pelo simples processo de multiplicação da renda que esta atividade propicia. Enquanto isso, $\mathrm{R} \$ 1,00$ de produtos agropecuários ou oriundos da indústria extrativa de minérios que são exportados gera $R \$ 1,4$ de PIB para o país (IPEA, 2011, p. 10).

O investimento na educação pública é mais rentável que o investimento público na iniciativa privada do agronegócio ou da mineração. Por essas e outras, Samuel de Abreu Pessoa, da Escola de Pós-Graduação em Economia da FGV, conta esta anedota

Desde os anos 1950, temos essa coisa engraçada: economista de direita defende a educação, economista de esquerda defende a indústria. É como na frase de Joãosinho Trinta: quem gosta de indústria e chão de fábrica é intelectual. O salário médio no setor de serviços é igual ao da indústria. $\mathrm{O}$ trabalho no setor de serviços é muito mais agradável, leve, urbano, com horário flexível. (PESSOA, 2012, s. p.)

Contradições ideológicas similares foram constatadas na pesquisa da OEI que envolveu uma amostra de 20.204 pessoas entrevistadas entre julho e agosto de 2011 em 18 países ibero-americanos (OEI, 2012, p. 30). Essa pesquisa concluiu que há uma "expectativa positiva sobre o futuro da educação pública em comparação com a avaliação do que aconteceu nos últimos dez anos. Mais da metade dos cidadãos acreditam que a educação será melhor no futuro" (OEI,

Olh@res, Guarulhos, v. 2, n. 1, p. 270-301. Maio, 2014. 
2012, p. 8). Essa esperança na educação parece fundamentar-se na avaliação positiva que os latino-americanos têm a respeito do:

conhecimento que os professores têm sobre as disciplinas que ensinam, (...). Em 10 países, mais de 80\% dos entrevistados disseram que os professores têm um bom conhecimento dos assuntos que ensinam e até mesmo em países com percentagens mais modestas quase dois terços dos cidadãos fez uma avaliação positiva. Essa avaliação é consistente com a elevada importância que os cidadãos concedem à formação de professores. (OEI, 2012, p. 66)

No entanto, apesar de considerarem excelente o trabalho e a formação dos professores, $41 \%$ dos entrevistados consideram que uma melhor formação de professores seria "um fator chave" para melhorar a qualidade dos sistemas de ensino e apenas "29\% incluem a melhoria do salário" para isso. Ora, se os docentes são bons como os cidadãos imaginam, por óbvio, mereceriam receber antes melhores salários que melhor formação. No caso brasileiro, conforme a concepção do FUNDEB, o salário dos educadores representa, no mínimo, 60\% do custo aluno qualidade. O Quadro abaixo serve para provocar o debate:

\section{Resultados do Relatório do PISA em Ciências - 2006}

Gasto Anual por Estudante - 2004

\begin{tabular}{|l|c|c|}
\hline País & $\begin{array}{l}\text { Desempenho Médio em } \\
\text { Ciências PISA 2006 }\end{array}$ & $\begin{array}{l}\text { Gastos Anuais } \\
\text { Médios por aluno (US\$) }\end{array}$ \\
\hline Finlândia & 563 & 7.441 \\
\hline Japão & 531 & 7.615 \\
\hline Coréia do Sul & 522 & 6.761 \\
\hline Alemanha & 516 & 7.576 \\
\hline EUA & 489 & 9.938 \\
\hline Irlanda & 508 & 7.110 \\
\hline Espanha & 488 & 6.701 \\
\hline Portugal & 474 & 6.168 \\
\hline Chile & 438 & 2.077 \\
\hline México & 410 & 1.922 \\
\hline Brasil & $\mathbf{3 9 0}$ & $\mathbf{1 . 0 3 3}$ \\
\hline
\end{tabular}

Fonte: Parecer CNE/CEB N N $^{\circ} / 2010$, aprovado em 5/5/2010. Aguarda homologação pelo MEC. Disponível em: http://portal.mec.gov.br, acesso em 15/10/2012.

A provocação é mecanicista, sem consideração pedagógica ou dialética, apenas pressupõe relação direta entre custo e desempenho. A nota dos alunos filandeses é 1,4 vezes maior que a dos brasileiros, mas a um custo 7,2 vezes maior. Nossos alunos atingem $70 \%$ da nota média em ciências dos melhores alunos do mundo, gastando $86 \%$ menos. Por absurdo, se o aprendizado é produto direto do custo, o que não é, os brasileiros seriam os alunos mais inteligentes do mundo: a um custo de US\$1.033, tiram a nota 390, se gastassem US\$7.441, triplicariam a nota dos filandeses. A pedagogia, no entanto, sabe que desempenho escolar é construído

Olh@res, Guarulhos, v. 2, n. 1, p. 270-301. Maio, 2014. 
por uma complexa teia socioeducativa, com alto investimento social, econômico, cultural e científico. Também é consequência da decisão política do eleitorado caso seja capaz de garantir seu direito à apropriação privada do ganho econômico produzido pela boa escolarização na sociedade do conhecimento.

Toda essa extensa discussão sobre o valor econômico da educação parece ajudar na disputa ideológica contra o senso comum que entende a educação de crianças como algo trivial e barato. O investimento público na oferta consistente e bem estruturada de programas de formação cotinuada para os professores da Educação Infantil e das séries iniciais do Ensino Fundamental representa um forte estímulo de longo prazo para o desenvolvimento econômico.

\section{O programa de formação continuada "Escola em Movimento: Saberes e}

\section{Fazeres em Cena"}

Entre os municípios do Rio Grande do Sul, Canoas ocupa o segundo lugar tanto pelo seu Produto Interno Bruto (PIB) quanto pelo tamanho de sua rede de ensino. Alguns dos dados do Censo Escolar do INEP 2012 ilustram a situação da Educação Básica da cidade:

\begin{tabular}{|c|c|c|c|c|c|c|c|c|c|}
\hline \multirow{5}{*}{ Escola } & \multicolumn{9}{|c|}{ Matrícula inicial } \\
\hline & \multicolumn{9}{|c|}{ Ensino Regular } \\
\hline & \multicolumn{4}{|c|}{ Educação Infantil } & \multicolumn{4}{|c|}{ Ensino Fundamental } & \multirow{2}{*}{$\begin{array}{l}\text { Ensino } \\
\text { Médio }\end{array}$} \\
\hline & \multicolumn{2}{|c|}{ Creche } & \multicolumn{2}{|c|}{ Pré- escola } & \multicolumn{2}{|c|}{ Anos Iniciais } & \multicolumn{2}{|c|}{ Anos Finais } & \\
\hline & Parcial & Integral & Parcial & Integral & Parcial & Integral & Parcial & Integral & Parcial \\
\hline Estadual & 0 & 0 & 9.657 & 0 & 4.636 & 1.095 & 7.094 & 651 & 9.657 \\
\hline Municipal & 0 & 1.359 & 0 & 1.199 & 14.171 & 2.383 & 9.232 & 871 & 0 \\
\hline SOMA & $\mathbf{0}$ & 1.359 & 9.657 & 1.199 & 18.807 & 3.478 & 16.326 & 1.522 & 9.657 \\
\hline
\end{tabular}

Fonte: Censo Escolar, disponível em http://portal.inep.gov.br/basica-censo-escolar-matricula

O total da matrícula na cidade atingia $22 \%$ das crianças em idade de frequentar creches e $47 \%$ das crianças entre 4 e 5 anos em escolas infantis, pelos dados do Censo 2010 do IBGE. O Ensino Fundamental matriculava 95,9\% das pessoas entre 6 e 14 anos. A universalização do Ensino Médio, prevista pela Lei $n^{\circ}$ $11.738 / 2008$, atendia apenas $68,2 \%$ dos jovens de 15 e 19 anos. $^{4}$

\footnotetext{
${ }^{4}$ Não foram consideradas as pessoas acima de 19 anos que não concluíram sua escolarização obrigatória.
}

Olh@res, Guarulhos, v. 2, n. 1, p. 270-301. Maio, 2014. 
Pensar em educação, indicadores de qualidade, diretrizes e metas, ensino e aprendizagens, formação continuada do Magistério, implica no redimensionamento do paradigma da docência como articulação inteligente entre diversos saberes sejam eles científicos, pedagógicos, pessoais, culturais, sociais, políticos, práticos e técnicos na perspectiva de garantir a melhor educação possível para crianças, adolescentes e adultos diante do novo cenário da Educação Básica, que atenda às demandas de uma nação cada vez mais democrática, justa, livre, equânime e solidária.

Alguns debates acerca de uma Plataforma estruturada na reflexão filosófica e científica delinearam o programa de formação continuada numa parceria entre a Secretaria Municipal de Educação de Canoas e o UNILASALLE ${ }^{5}$, denominado "Escola em Movimento: Saberes e Fazeres em Cena" que integra o Núcleo do Observatório da Educação do Mestrado em Educação, a partir do projeto de pesquisa “Alfabetização nos Anos Iniciais do Ensino Fundamental e Formação de Professores na Rede Municipal de Ensino de Canoas: a pesquisa-ação colaborativa como elemento de qualificação das práticas educativas" aprovado pelo Edital No 038/2010/CAPES/INEP, coordenado por Dirléia Fanfa Sarmento, iniciado em 2010 e concluído em 2013.

O início da pesquisa consistiu no levantamento de dados qualitativos a partir de entrevistas e relatos de professores, diretores e gestores municipais, no curso de 2009, produzindo sínteses a partir dos indicadores expressos através do sistema de avaliação, do quadro de recursos humanos e das recorrências da não aprendizagem. Sendo assim, de forma objetiva, o problema de pesquisa do Observatório da Educação é: como determinar e influir em fatores que levem à melhoria da qualidade da alfabetização nos Anos Iniciais do Ensino Fundamental, levando em conta dados históricos, estatísticos e qualitativos, tendo como referência os indicadores de desempenho dos alunos das escolas municipais fornecidos pelo Sistema de Avaliação da Educação Básica (SAEB) do INEP, em especial pelo Provinha Brasil; cotejando-os com os resultados produzidos pelo

\footnotetext{
${ }^{5}$ Em 2014, o Centro Universitário La Salle - UNILAS ALLE - reúne mais de 8 mil alunos em 40 cursos de graduação e 5 Programas de Pós-graduação. Localiza-se em Canoas, município da Região Metropolitana de Porto Alegre, no Rio Grande do Sul. Os Irmãos lassalistas instalam-se na cidade em 1908. Em 1942, criaram a Escola Normal La Salle, a primeira escola privada do Rio Grande do Sul destinada à formação do magistério primário.
}

Olh@res, Guarulhos, v. 2, n. 1, p. 270-301. Maio, 2014. 
Sistema de Avaliação da Educação Municipal (SAEM) - Canoas Avalia ${ }^{6}$ ? De posse, portanto, de tais registros, um cenário nebuloso se avistava pela incidência de reprovações principalmente nos anos iniciais. A Secretaria de Educação empunhou a bandeira político-pedagógica do enfrentamento de tais indicadores compondo a parceria cujo campo investigativo, portanto, são dezessete escolas de Ensino Fundamental pertencentes à Rede Municipal de Ensino da Cidade de Canoas vislumbrando a superação de tais resultados a partir de uma proposta formativa na perspectiva metodológica que contempla a investigação, a ação, a intervenção e a reflexão crítica.

Uma visão sistêmica de educação, segundo a qual a reprovação não é problema exclusivo da escola ou do professor, tampouco do aluno, mas se caracteriza por um complexo conjunto de elementos inibidores dos processos de ensino e aprendizagem, o papel da universidade se torna essencial na busca de soluções desencadeadoras da qualidade social da educação. Nesta perspectiva, foram constituídos os ciclos formativos compreendendo desde a formação continuada das dezessete escolas com baixo rendimento nos anos iniciais, curso de extensão nas áreas da matemática, linguagem e ciências, curso de extensão para gestores e coordenadores pedagógicos - até os de especialização (na pós-graduação lato sensu) e de mestrado e posteriormente Doutorado (no stricto sensu). Pretende-se que essa dinâmica se constitua como ato contínuo de uma relação com a pesquisa acadêmica inserida no cotidiano das escolas e, respectivamente, da inserção das escolas no cotidiano dos grupos de pesquisa do Programa de Pós-Graduação.

Tal proposta visa a um modelo de formação onde os professores reflitam sobre suas práticas, articulando-as às teorias de forma dialogal. O diálogo entre as teorias e as práticas propõe a busca de soluções para os desafios impostos pela atualidade, construindo hipóteses e afirmando conceitos, testando-os, a partir da concepção do ensino reflexivo, que, conforme propõe Nóvoa, seria a forma de olhar para as nossas próprias ações, identificando-as e reinventando-as porque valoriza

\footnotetext{
${ }^{6}$ Canoas Avalia é instrumento diagnóstico-avaliativo que compõe o SAEM - Sistema de Avaliação Municipal instituído pelo Decreto 832 de 11/08/2009 da Prefeitura de Canoas/RS. Disponível em: http://www.leismunicipais.com.br/legislacao-de-canoas/797274/decreto-832-2009-canoas-rs.html, acesso em 15/10/2012.
}

Olh@res, Guarulhos, v. 2, n. 1, p. 270-301. Maio, 2014. 
paradigmas de formação que promovam a preparação de professores reflexivos, que assumam a responsabilidade do seu próprio desenvolvimento profissional e que participem como protagonistas na implementação das políticas educativas. (1992, p. 27)

Ao refletir sobre sua prática, o professor desenvolve uma ação investigativa que irá formá-lo como promotor de conhecimentos sobre o ensino e a aprendizagem, superando a concepção de que seria apenas um sujeito limitado a reproduzir conhecimentos produzidos pelos pensadores da educação. Ao propor uma formação estruturada em torno da reflexão sobre suas práticas, cabe considerar a atuação do professor no contexto particular no qual o trabalho educativo se desenvolve numa perspectiva emancipatória de formação humana. Tal plataforma instituiu-se como uma política pública totalmente custeada pelo poder público municipal, contemplada no já referido novo Plano de Carreira do Magistério Público Municipal de Canoas, a partir de 2011:

Considera-se, para efeitos de aplicação deste artigo, como indução, a indicação de área, de curso ou de linha de pesquisa, pela SME, com base em diagnóstico de demanda, para desenvolvimento de capacitação e de pesquisa, tanto em grau de especialização, como de mestrado e de doutorado (Lei 5.580/11, Art. 31, Parágrafo Único).

Assim, para ilustrar o ciclo formativo pertencente à "Plataforma de Formação Escola em Movimento, Saberes e Fazeres em Cena" foi elaborado esse esquema dos ciclos formativos:

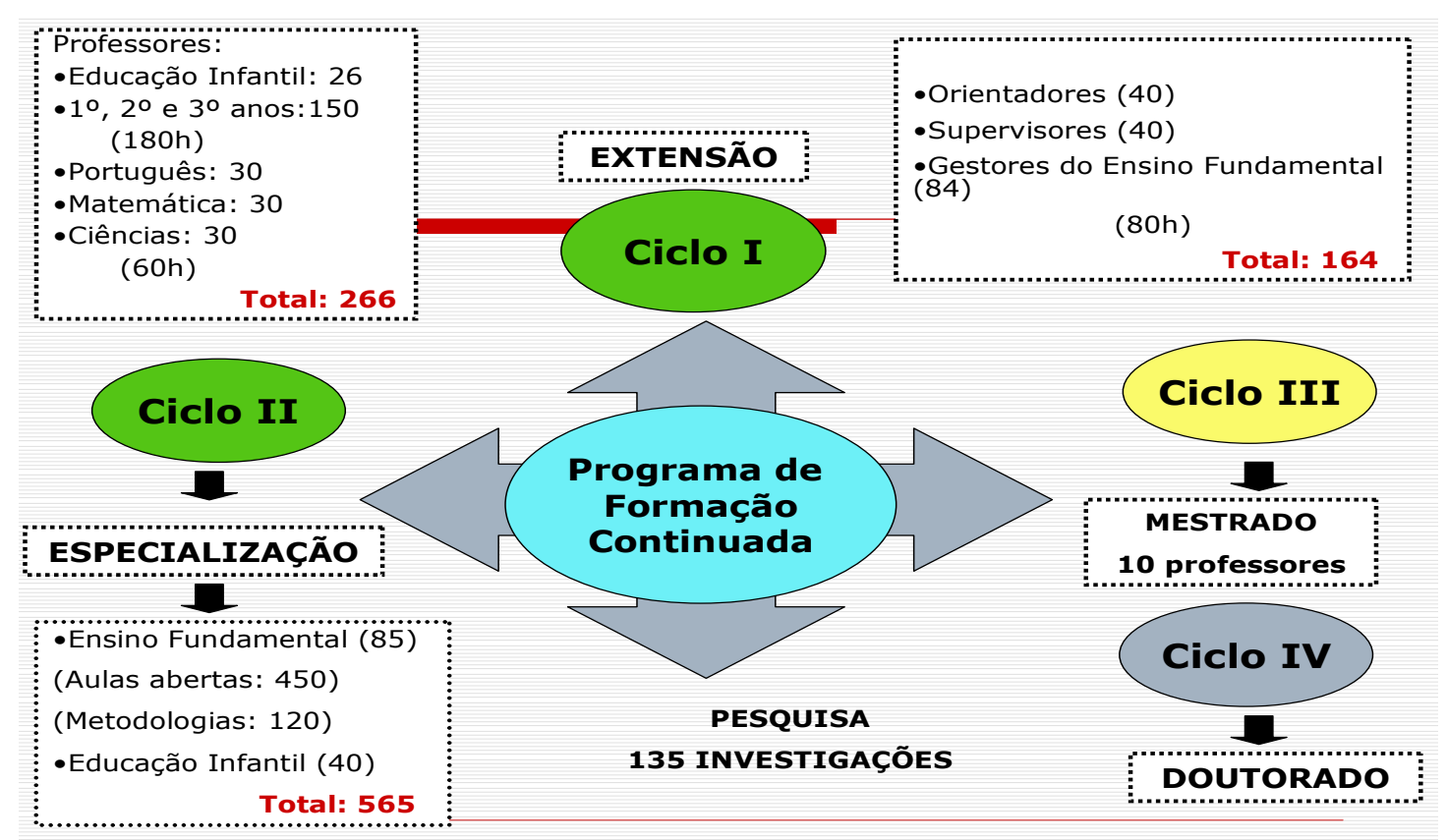

Olh@res, Guarulhos, v. 2, n. 1, p. 270-301. Maio, 2014. 
O Ciclo I responde às necessidades de superação de indicadores expressos no IDEB e no Canoas Avalia, como anteriormente abordado, abrangendo, além das dezessete escolas, o grupo no entorno destas, desde as equipes diretivas, como também as turmas de crianças da educação infantil como futuros ingressantes no ensino fundamental - 23 professores - cujas instituições de educação infantil situam-se territorialmente no entorno das escolas envolvidas na pesquisa.

O Ciclo II amplia os temas para um processo de formulação de pesquisas no âmbito das necessidades observadas, sob o olhar cirúrgico da intervenção social apoiada cientificamente, a partir dos "problemas" que se pretende solucionar. A investigação, portanto, assume a caracterização dos tais "problemas" que foram chamados, inicialmente, pela atual gestão, de demandas. Estas serão pormenorizadas na busca de novas descobertas para os velhos problemas que circulam a vida na e da escola. Assim, um processo seletivo público foi aberto para que todos os professores do ensino fundamental interessados concorressem com as mesmas oportunidades para as oitenta e cinco vagas, escolhendo, no ato da inscrição, seu tema de interesse, e de acordo com as linhas de pesquisa do UNILASALLE, a partir de oito eixos temáticos:

1. Políticas Públicas Municipais na área da Educação;

2. Gestão Educacional no contexto escolar;

3. Educação e processos inclusivos no ensino fundamental;

4. Formação de professores e práticas educativas no Ensino Fundamental;

5. Organização da ação pedagógica no ensino fundamental: proposta pedagógica, planos de estudos, currículo, planejamento e avaliação dos processos de ensino e de aprendizagem;

6. Metodologias de ensino: alfabetização e letramento, língua portuguesa, matemática e ciências;

7. Integração das tecnologias no contexto escolar;

8. Relação entre família e escola.

$\mathrm{Na}$ mesma concepção, à educação infantil foi possível oferecer semelhante processo de ingresso, respeitados, contudo, os temas atinentes àquela realidade, $\mathrm{e}$ num percentual relativo ao contingente de profissionais da área, somando quarenta professores nestes eixos:

1. Fundamentos do trabalho pedagógico na Educação Infantil: rotinas pedagógicas e planejamento docente;

2. A Educação e o cuidado na infância;

3. Educação Infantil e Ensino Fundamental: interfaces necessárias;

4. Direitos Humanos Infantis: a educação e o cuidado na infância;

5. O sujeito infantil na contemporaneidade;

6. Qualidade na Educação Infantil: a gestão pedagógica, profissionais qualificados, ambiente escolarizado, infraestrutura;

Olh@res, Guarulhos, v. 2, n. 1, p. 270-301. Maio, 2014. 
O brincar e suas implicações no cotidiano escolar associado às práticas educativas;

7. A relação familiar e escola: relações necessárias para adaptações das crianças na educação infantil.

O Ciclo III foi planejado para aprofundar os temas abordados no ponto anterior, com proposta mais minuciosa, foi viabilizada a participação de dez docentes da rede como bolsistas para a realização de suas dissertações nas linhas de pesquisa acadêmica do Mestrado com foco na interface dialógica com a gestão do sistema municipal de ensino, com a avaliação nacional e local do rendimento dos alunos na alfabetização e com as práticas de ensino-aprendizado nas salas de aula da Educação Infantil e dos anos iniciais e os processos de autoformação em serviço dos docentes. Também, num processo de seleção pública, os integrantes, professores da rede municipal, assumem a tarefa de produzir as investigações e as sínteses em torno das temáticas recorrentes de suas realidades escolares, sujeitos pesquisadores e reflexivos de seus próprios fazeres docentes.

O programa é subsidiado pela Prefeitura Municipal e a pesquisa aspira consolidar a parceria existente entre a academia e a gestão do sistema municipal de ensino de Canoas no que se refere ao compromisso com a formação continuada dos professores e gestores municipais e estimular investigações na pós-graduação. Consolida-se, portanto, a relação entre o conhecimento científico e a escola, articulando-se com as reais necessidades sociais e culturais num circuito interativo, produzindo outros conhecimentos a partir da experiência. Essa, por certo, é uma das funções da universidade. Moita e Andrade afirmam que a

[...] extensão e o ensino não são acessórios à pesquisa, mas continuações naturais delas, se a produção científica do conhecimento quiser ser efetiva e intervir para modificar a realidade estudada voltando a enriquecer-se, nesse processo, por dela alimentar-se continuamente. Donde não haver relevância social da pesquisa sem a indissociabilidade. (MOITA; ANDRADE, 2009, p. 279)

O próximo esquema apresenta as estratégias utilizadas nos processos metodológicos que foram pensados para articular os demais educadores da rede pública do município com o projeto de formação continuada, buscando construir uma teia formativa que criasse as condições para facilitar o diálogo e possibilidade de produzir sínteses coletivas acerca da experiência docente. Nesse sentido foram criados os Seminários Temáticos.

Olh@res, Guarulhos, v. 2, n. 1, p. 270-301. Maio, 2014. 


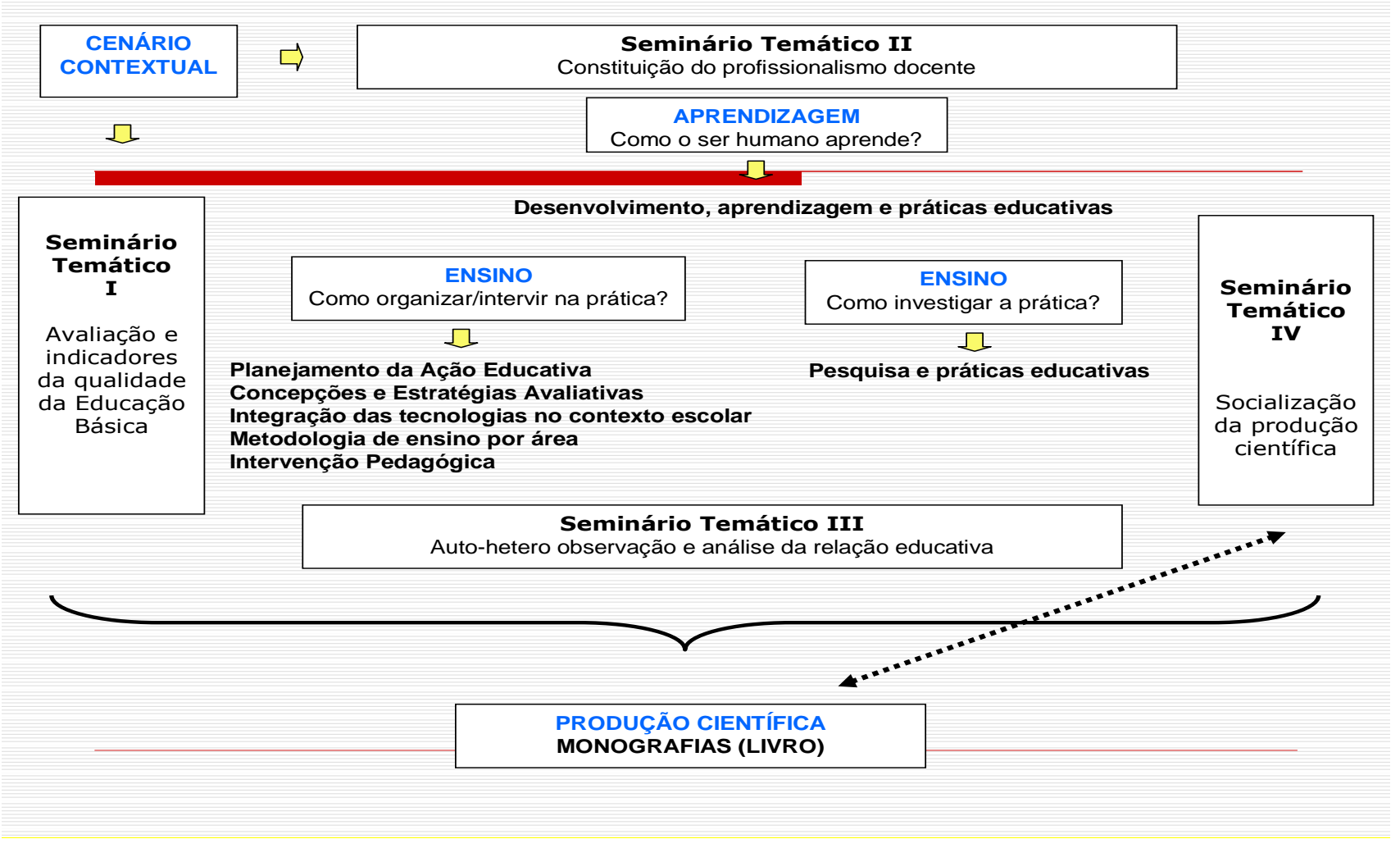

\subsection{Avaliação preliminar do primeiro ano de execução do programa}

As metas quantitativas do programa foram atingidas. Para os 250 professores interessados na especialização, foram disponibilizadas 80 vagas no curso "Ação Educativa no Ensino Fundamental" destinado aos docentes em exercício no ensino fundamental e 40 vagas no curso "Ação Educativa na Educação Infantil”, para os docentes em exercício na Educação Infantil, previstas no convênio. Para o primeiro curso de especialização, pela relevância dos temas dos memoriais descritivos foram selecionados 85 docentes que receberam bolsa integral. No curso da Educação Infantil, cujo contingente interessado ultrapassava uma centena de professores, o processo de seleção recebeu 41 inscritos e somente 35 realizaram a prova seletiva, com apenas uma reprovação.

A etapa seguinte respondeu à necessidade de um processo seletivo para o ingresso no Mestrado em Educação, cuja estimativa era superior a 150 interessados. A Secretaria organizou uma inscrição prévia com orientações acerca do programa, numa ampla e instigante divulgação junto à rede escolar preparatória ao processo seletivo. A segunda etapa foi realizada pelo Programa de Mestrado em Educação conforme o Edital de seu processo seletivo. Dos docentes indicados pela Prefeitura, 79 inscreveram-se como os demais candidatos que totalizaram, no

Olh@res, Guarulhos, v. 2, n. 1, p. 270-301. Maio, 2014. 
processo seletivo para 2012, 132 candidatos que concorreram nas mesmas condições. A única "vantagem competitiva", para usar um termo mercadológico que destaca o "inédito-viável" deste processo seletivo peculiar, consistia no fato óbvio de que os docentes municipais redigiram seu Memorial Descritivo contendo um esboço de projeto de pesquisa que, pela sua natureza, atendia, a priori, aos critérios da viabilidade de realização da pesquisa, da sua relevância social e contribuição para a Educação Básica. As candidaturas dos docentes da rede municipal de Canoas atendiam quatro condições de viabilidade: $a$ ) segurança financeira para o pagamento das mensalidades e, portanto, de permanecerem no programa de uma IES particular; $b$ ) o aceite formal da Secretaria Municipal de Educação para a realização da pesquisa em uma ou mais escolas do sistema municipal de ensino; c) a relevância social do projeto, atestada pela declaração explícita dos gestores desta rede de ensino; $d$ ) a inserção já existente no campo empírico da pesquisa. Com a garantia da viabilidade da pesquisa, assegurados os critérios acadêmicos de aderência à linha de pesquisa e à capacidade de orientação por parte do Programa, e, por outro lado, a qualidade acadêmica da candidatura demonstrada na prova escrita, no Memorial e na entrevista, justificou a aprovação de dez professores da rede, compondo metade da turma ingressante em 2012/1.

$\mathrm{Na}$ prática, portanto, este trabalho realiza uma avaliação provisória referente à experiência letiva de 129 professores da rede municipal matriculados em diferentes cursos do programa de formação. Destaca-se a experiência inédita e viável vivenciada pelos dez professores que, de forma coletiva e articulada com a sua rede de ensino, novamente, assumem a condição discente em um Programa de Mestrado.

A concepção deste programa de formação continuada partiu de uma proposta que precisou basear-se em alguns ideais pedagógicos porque não havia nenhum acúmulo prático de experiências anteriores a partir das quais se pudesse planejar um processo de formação continuada realizado de forma articulada entre gestores municipais de educação, pesquisadores de um PPG em Educação e docentes dos anos iniciais do ensino fundamental na perspectiva teórica da pesquisa-ação. Alguns pesquisadores do PPG em Educação do Unilasalle haviam utilizado esse recurso metodológico com um pequeno grupo de professores de uma escola municipal de Porto Alegre, visando à “construção do conhecimento, destacando,

Olh@res, Guarulhos, v. 2, n. 1, p. 270-301. Maio, 2014. 
substancialmente, a melhoria continuada, sistemática e empiricamente fundamentada para aprimorar a prática” (SILVA; NÖRNBERG; PACHECO, 2012, p. 97). Assim,

a partir de uma experiência em andamento, levado a efeito por um coletivo de professores da educação básica que, retroalimentados por espaços de socialização de práticas de docência, deram-se conta do vitalismo de suas ações e buscaram formas de fortalecê-las e promovê-las a fim de multiplicá-las, criando uma espécie de rede estratégica não intencional. Esse movimento, em primeiro lugar, acabou gerando uma busca coletiva por melhores formas de compreender e atuar em torno de um problema comum (...). (SILVA; NÖRNBERG; PACHECO, 2012, p. 98)

O projeto, então, foi idealizado a partir da metodologia da pesquisa-ação e executado nos limites das possibilidades político-pedagógicas de uma rede municipal. De um lado, o cenário de implementação inicial do curso de formação continuada dos docentes estava marcado por dificuldades e sofrimentos, no qual os indicadores de reprovação beiravam o percentual de vinte por cento, ou seja, cerca de seis mil crianças reprovadas ao ano. Por outro lado, uma mudança positiva somou-se ao cenário com a aprovação da Lei Municipal n 5580, de 11 de fevereiro de 2011 que estabelece o Plano de Cargos, de Carreira e de Remuneração do Profissional do Magistério do Município de Canoas. ${ }^{7}$ Vale destacar o Capítulo IV que define o "Aperfeiçoamento Contínuo" dos docentes nos seguintes artigos:

Art. 25. Aperfeiçoamento é o conjunto de procedimentos que visam a proporcionar ao professor a atualização e a valorização pessoal e profissional para a melhoria contínua da qualidade da atividade educacional e para o desenvolvimento de suas competências.

$\S 1^{\circ} \mathrm{O}$ aperfeiçoamento de que trata este artigo é desenvolvido mediante a integração do professor em programa permanente de capacitação, instituído pela SME, para participar de cursos internos e externos, conforme a natureza e complexidade da função de magistério e dos projetos especiais a serem desenvolvidos.

$\S 2^{\circ}$ Cabe à SME realizar diagnóstico de treinamento e de capacitação, visando a aperfeiçoar o professor, oferecendo oportunidades para realização de atividades complementares e induzindo a agregação de grau, por demanda de área.

$\S 3^{\circ}$ Independente das oportunidades proporcionadas pela Administração, será considerado como mecanismo de indução de grau, o curso realizado pelo professor se dentro da área indicada no diagnóstico da SME na forma do $\S 2^{\circ}$ deste artigo. (Redação dada pela Lei ${ }^{\circ}$ $5821 / 2014)$

Art. 26. A SME editará anualmente regulamento definindo os critérios, as condições e as modalidades para a concessão de bolsa de estudo ou outra forma de financiamento público para o desenvolvimento de capacitações.

$\S 1^{\circ}$ Os critérios a serem observados deverão contemplar necessariamente:

\footnotetext{
${ }^{7}$ Disponível em: https://www.leismunicipais.com.br/a/rs/c/canoas/lei-ordinaria/2011/558/5580/plano-de-caragos-ecarreiras-canoas-2014-02-24.html
}

Olh@res, Guarulhos, v. 2, n. 1, p. 270-301. Maio, 2014. 
I - processo público e aberto de seleção;

II - ampla divulgação, inclusive no ambiente de cada escola;

III - formação de banca examinadora por profissionais especializados e externos à administração direta;

$\S 2^{\circ}$ Só poderá participar do processo de seleção o profissional do magistério em efetivo exercício da docência ou em funções de suporte pedagógico à docência.

Assim, a progressão na carreira docente é estimulada pela legislação educacional, em um aspecto central de qual política pública educacional: a remuneração e a qualificação do magistério. Ao vincular estas duas dimensões, a legislação educacional canoense exige que a Secretaria Municipal produza constantes diagnósticos de suas escolas para induzir os processos de qualificação permanente de seus docentes, vinculando prática e teoria na concretude da vida dos docentes e de seus mecanismos institucionais de formação permanente. O aperfeiçoamento, assim caracterizado, visa a proporcionar ao professor a atualização e a valorização pessoal e profissional para a melhoria contínua da qualidade da atividade educacional e para o desenvolvimento de suas competências. A oferta de "cursos induzidos" torna-se critério para a progressão de carreira, articulando o processo de aperfeiçoamento profissional às necessidades de qualificação dos processos de ensino e aprendizagem da rede de ensino, diagnosticados pelos índices de qualidade da educação.

Ainda, num quadro político em que se instaurava um governo que se identificada com o campo da esquerda, vitorioso nas eleições de 2008, cujos pressupostos ideológicos se fundamentavam no diálogo crítico e permanente como exercício da democracia. Portanto, profundas mudanças no campo educacional eram desejadas e sonhadas rompendo com concepções dogmáticas e tecnocráticas. A esperança alicerçava a ânsia e urgência por mudanças, sem, no entanto, impor "receitas" governamentais que não respondiam às necessidades educacionais, profissionais e pessoais do Magistério.

Assim, realizou-se um processo de diálogo entre a Secretaria de Educação e os professores, através dos grupos de assessorias e apoio às escolas, iniciado em diferentes espaços e momentos. O exercício de escuta permanente possibilitava identificar os sintomas, ajustar as incertezas, desdizer o não dito e reafirmar velhas e novas certezas no campo da teoria pedagógica e da prática escolar. Dentre os tantos momentos, por entre as falas do grupo, algumas expressões faziam referência à Plataforma, cujas críticas apontavam para certa ineficiência

Olh@res, Guarulhos, v. 2, n. 1, p. 270-301. Maio, 2014. 
curricular e metodológica. Dentre os apontamentos, estavam os de que o corpo docente da Secretaria Municipal de Educação era composto pelos mesmos profissionais vinculados à mantenedora, os quais acumulavam "vícios" de outras gestões "sempre os mesmos", quais sejam, os seus assessores interlocutores pedagógicos. Restringiam-se, segundo estas falas, a estudos das diretrizes curriculares municipais e orientação para refinamento do tema da pesquisa, conteúdos dissociados da proposta inicial de investigação, que tinha como pressuposto fundamental a pesquisa-ação. Tais manifestações demarcam a necessidade de uma avaliação mais específica da proposta curricular e dos fundamentos da plataforma, mesmo porque a necessidade que levou a elaborar as diretrizes necessitava ser mais amplamente discutidas com todos os docentes do UNILASALLE envolvidos na proposta curricular da Plataforma formativa.

A reflexão, análise e avaliação da proposta pedagógica, basicamente no que tange à metodologia, deve ser a premissa que orienta a conduta tanto do gestor como da instituição parceira, na busca de vínculos assumindo a mútua responsabilidade pela qualidade da educação e o desenvolvimento do ser humano, pois esta reflexão

também significa o reconhecimento que a produção de conhecimentos sobre o que é um ensino de qualidade não é prioridade exclusiva das universidades e centros de investigação e desenvolvimento e de que os professores também têm teorias que podem contribuir para uma base codificada de conhecimentos de ensino. (ZEICHNER, 1993, p.16)

Uma primeira dificuldade identificada no campo da metodologia da pesquisa-ação refere-se a um de seus pressupostos: a socialização das investigações entre os pares como prática cotidiana, permanente e temporalmente intensa. Quando um grupo de professores/pesquisadores compartilha seus fazeres docentes com seus pares no âmbito acadêmico produzem novas reflexões e geram novas sínteses capazes de dialogarem com tantas outras situações. A angústia desses docentespesquisadores surge quando percebem a sua investigação como um ato mecânico. Esse fato impõe à mantenedora e à instituição parceira uma agenda permanente para analisar e superar estes sentimentos, situações e discursos, aprimorando e qualificando a prática coletiva da pesquisa. Caso contrário, incorre-se no risco de repetir os modelos acadêmicos tradicionais voltados à produção de pesquisas demandadas mais pela academia do que pela necessidade de intervenção efetiva e transformadora nas práticas das salas de aula da Educação Infantil e das séries iniciais do ensino fundamental. Da mesma forma, corre-se o risco de repetir as

Olh@res, Guarulhos, v. 2, n. 1, p. 270-301. Maio, 2014. 
soluções de mercado oferecidas pelas prestadoras de serviços pedagógicos que vendem às Secretarias de Educação, pacotes fechados de formação continuada para consumo imediato dos docentes. O cerne da plataforma, ao contrário, está exatamente na superação tanto de uma situação, quanto da outra. Essa dificuldade se apresenta no campo da pesquisa sobre a "formação do professor" posto que ela deva dialogar com os "pontos de vista dos próprios implicados" e com a opinião de todos

sejam esses alunos, seus pares, membros da comunidade escolar ou acadêmica, sem esquecer o confronto com o conhecimento acumulado sobre o tema disposto pela tradição cultural em toda a sua amplitude. Poderíamos ter nesse sentido uma compreensão mais fundamentada do tema não "sobre", nem "em" e nem "para", mas "com" a formação de professores, o que pode levar, em tese, a resultados completamente opostos daqueles tomados pela consulta a um único segmento. (DEVECHI; TREVISAN, 2011, p. 424)

Uma segunda dificuldade são as limitações, ainda no campo da metodologia, para a realização da pesquisa-ação no contexto de uma rede de ensino, viabilizada pela parceria entre pesquisadores, alguns na condição de professores da Educação Básica e outros na de docentes da Pós-Graduação. Diante do desafio de estarem juntos refletindo sobre a prática, cabe pensar, sobretudo, numa formação continuada do Magistério a partir de vertentes epistemológicas e humanistas que se entrecruzam na vida pessoal e profissional dos educadores. O que não é, de modo algum, trivial. Talvez a reflexão sobre a experiência de inserção docente de François Dubet ajude na superação dessa dificuldade metodológica. Desafiado pelos professores do ensino fundamental, o pesquisador resolveu dar aulas de história e geografia para alunos de 13/14 anos, numa escola da periferia de Bordeaux. A partir dessa experiência, ele constata que a relação entre a pesquisa e a ação docente é complexa, envolvente e difícil de ser vivida:

Quando se pede a um professor para mudar o seu método, não se pede apenas que ele mude de técnica, pede-se para que ele próprio mude. E, no fundo, a gente vê muito bem o tipo de sabedoria professoral, que não é um absurdo, quando os professores dizem: "Existem métodos que me servem e métodos que não me servem." A gente vê professores que adotam métodos tradicionais que funcionam muito bem e outros que têm métodos ativos que funcionam. Mas a gente vê também professores que se obrigam a aplicar métodos que não são os seus e não dá certo. E aliás, os alunos são muito sensíveis a este tipo de adequação da personalidade do professor e de seu estilo pedagógico. Temos então interesse em deixar uma multiplicidade de métodos possíveis. (DUBET, 1997, p. 226)

Olh@res, Guarulhos, v. 2, n. 1, p. 270-301. Maio, 2014. 
Articular as pesquisas em educação com os métodos de qualificação do aprendizado na sala de aula é um desafio científico não apenas para o Programa de Pós-Graduação do Unilasalle, mas para a comunidade científica da educação. Um desafio assumido pelo Plano Nacional de Pós-Graduação - PNPG 2011-2020 que reconhece a sala de aula da Educação Básica como um lócus privilegiado da formação permanente dos professores:

\begin{abstract}
A compreensão da educação como um direito e como um processo formativo contínuo e permanente amplia as tarefas dos profissionais da educação, particularmente no que diz respeito às práticas na sala de aula. Exige-se do professor que ele seja capaz de articular os diferentes saberes escolares à prática social e ao desenvolvimento de competências para o mundo do trabalho. Em outras palavras, a vida na escola e o trabalho do professor necessitam ser repensados. Como consequência, necessitamos repensar a formação dos professores para que eles possam enfrentar as novas e diversificadas tarefas que lhes são confiadas. (BRASIL, 2010, p. 167-168)
\end{abstract}

Para garantir o caráter "inédito-viável” deste programa de formação continuada dos professores de Canoas/RS, há de se estabelecerem relações de pesquisa que precisam ainda desenvolver objetivos cada vez mais claros sobre como se efetiva o processo de orientação, como é possível assegurar a devolutiva da pesquisa para as escolas, como socializar a produção coletiva do conhecimento docente. A dificuldade se agrava porque a cultura e a estrutura da pós-Graduação estão centradas na defesa individual do projeto e da dissertação, de modo que é ainda mais difícil mensurar os efeitos da pesquisa sobre a prática e da prática sobre a pesquisa de forma coletiva entre os pesquisadores e dentro da própria rede! Desse modo, a formação docente neste programa construiu um desenho possível ainda inconcluso para a sua marca e a sua diferença, visando ao atendimento dos anseios do sistema de ensino, da escola e do docente. De algum modo, a formação permanente dos docentes da Educação Básica pauta a academia para a busca simultânea, coletiva e participativa de novas respostas para os problemas cotidianos, as interrogações que permanecem na escola básica, na formação inicial dos docentes e nas linhas de pesquisa do programa de pós-graduação. Em síntese, pensando em sistema de ensino, a questão é como superar o afastamento sistêmico entre os programas de pós-graduação vinculados ao sistema federal de ensino (LDB, art. 16), e as escolas de um sistema municipal de ensino (LDB, art. 18). Desse modo, produziu-se uma dicotomia entre os sistemas que deveriam estar articulados de forma sistêmica, colaborativa e complementar característica de um sistema nacional de educação em uma república federativa. Essa dicotomia afeta de forma peculiar os programas de formação continuada de professores.

Olh@res, Guarulhos, v. 2, n. 1, p. 270-301. Maio, 2014. 
Essa dicotomia entre a formação inicial e a formação continuada, segundo Gatti, dificultou que muitas das iniciativas públicas de educação continuada de professores resultassem, de fato, no "aprimoramento de profissionais nos avanços, renovações e inovações de suas áreas, dando sustentação à sua criatividade pessoal e à de grupos profissionais, em função dos rearranjos nas produções científicas, técnicas e culturais". Para essa pesquisadora, pelo contrário, a formação continuada, na sua primeira década de realização após a promulgação da LDB, caracterizou-se por iniciativas de formação limitadas a suprir a "precariedade em que se encontram os cursos de formação de professores em nível de graduação" (GATTI, 2008, p. 58). De forma semelhante, tal desvinculação sistêmica afetou também os Programas de Pós-Graduação, nos quais,

\begin{abstract}
quando se faz pesquisa, predomina um tipo de investigação que transforma a escola, os sistemas de ensino, o corpo docente das escolas, suas práticas, etc. em "objetos" de pesquisa. Portanto, predomina, quando voltada à escola, a pesquisa mais de ordem utilitária, sobre a EB [Educação Básica - nossa nota] e seus agentes e não com ou para eles. (BIANCHETTI; RISTOFF, 2012, p. 203)
\end{abstract}

\title{
3.2 Prospectando os desafios político-pedagógicos da experiência de formação
}

A superação dos impasses político-pedagógicos no cenário contraditório da escola pública municipal de Canoas e dos desafios desta experiência de formação continuada de seus docentes parece passar pela reflexão teórica sobre a própria prática. Este trabalho fez uma primeira avaliação da recente experiência desta rede viabilizada pela parceria entre a Secretaria de Educação de Canoas/RS e o Núcleo Observatório da Educação do Mestrado em Educação do UNILASALLE. A proposta metodológica pretendida foi a pesquisa-ação no contexto de formação envolvendo os inúmeros conceitos que perpassam os processos de ensino e aprendizagem comuns a todos os agentes, possibilitando a construção de estratégias de intervenção pedagógica nos seus múltiplos fazeres cotidianos, intervindo na superação de alguns dos "problemas" que se apresentam nas realidades escolares. A Plataforma de formação propôs e propõe espaços formativos e subsídios teórico-metodológicos que viabilizem a reflexão, a avaliação e a projeção de estratégias de caráter intervencionista para qualificar as práticas educativas e a produção do conhecimento pedagógico de professores capazes de gerir situações complexas de aprendizagem incidindo na melhora dos

Olh@res, Guarulhos, v. 2, n. 1, p. 270-301. Maio, 2014. 
indicadores de desempenho dos alunos da Educação Básica da rede Municipal de Canoas e na qualidade da educação para o conjunto de sujeitos envolvidos no processo.

A experiência de formação continuada de professores na perspectiva aqui delineada possui um potencial político-pedagógico transformador que se objetiva, de um lado, pela mudança concreta na vida de cada discente que, de fato, passa a aprender e que, na própria experiência do aprendizado, passa a reconhecer-se como portador do direito a melhor educação que o conhecimento acumulado pela humanidade tem a lhe oferecer; de outro lado, se concretiza no exercício profissional de quem, de fato, é capaz de ensinar e que, pela própria experiência do ensino, objetivamente passa a se reconhecer e a ser reconhecido pela dignidade de quem professa o conhecimento acumulado pela humanidade diante da sua própria e da nova geração.

A produção do "conhecimento de experiência feito" (FREIRE, 2001, p. 35), desde as séries iniciais do ensino fundamental, constitui-se em oportunidade para a pedagogia superar o senso comum do Magistério para assumir a condição de profissional com formação superior, portanto, capaz de viver pessoal e profissionalmente a condição existencial de sujeito produtor de conhecimento científico. A disseminação dessa concepção científica da educação parece ser interessante para a qualificação da opinião pública, superando preconceitos do senso comum, acerca da relevância estratégica das Prefeituras manterem a qualificação permanente dos profissionais da educação que atuam na rede municipal. Esse avanço objetivo na consciência política da cidadania incidirá, senão mesmo criará uma legitimação na opinião pública eleitoral capaz de priorizar a política educacional numa sociedade do conhecimento que seja também mais democrática e justa.

Um projeto político-pedagógico que se proponha a criar condições cognitivas e sociais para a ampliação da democracia e da prática da justiça social parece ter o potencial de recuperar uma das principais tradições pedagógicas brasileiras para os desafios da escola pública contemporânea: a Educação Popular, no sentido de educação de cada pessoa do povo brasileiro. Nesse sentido, Ricci propõe a necessidade de identificar os "desafios recentes da educação popular no Brasil”". O autor o faz a partir de sua avaliação sobre as duas gestões do governo Lula.

Olh@res, Guarulhos, v. 2, n. 1, p. 270-301. Maio, 2014. 
Sua tese, embora polêmica e insipiente, parte do fato de que as lideranças populares dos movimentos sociais foram moldadas pela Educação Popular, ao longo das últimas quatro décadas. Essas lideranças aprenderam a sustentar um "discurso emocional e muitas vezes populista" que "questionava a capacidade do sistema institucional absorver as demandas concretas difusas", tal como nos parece ser o caso da demanda por formação continuada de professores públicos. A experiência analisada por nós nesse trabalho parece enquadrar-se nesse caso. Ricci conclui que as lideranças populares que assumiram a gestão dos sistemas institucionalizados se colocam diante de "três possibilidades no rearranjo do sistema de representação dos movimentos sociais". Ou elas sucumbem à cooptação ou separam sua militância política de sua atuação governamental. Para Ricci, há um terceiro tipo que chama de "representação delegada" pela qual "o discurso genérico e universal da liderança se dissipa, torna-se menos emocional e mais técnico e propositivo" (RICCI, 2010, p. 239). Talvez seja possível uma síntese dialética entre, de um lado, o discurso técnico de lideranças do movimento social docente que, democraticamente, foram alçadas à direção política do sistema de ensino com o discurso emocional daqueles docentes da rede que mantém o discurso da Educação Popular que ressalta o fracasso das escolas formais e dos sistemas de ensino diante das necessidades formativas populares.

Talvez seja possível construir um conhecimento pedagógico que mantenha tanto a formalidade institucional necessária à gestão do sistema de ensino, quanto à emocionalidade peculiar dos movimentos sociais dos docentes, de forma a construir a qualidade do aprendizado na escola e a qualidade social da própria educação. Seria possível conciliar a objetividade necessária ao governante com a subjetividade necessária ao educador? Essa reconciliação parece plausível porque a experiência iniciada com esse programa de formação permanente está permitindo tanto aprender a ser governo, sem tornar-se necessariamente governista; quanto aprender a ser educador da rede pública, sem tornar-se necessariamente oposicionista! Essa síntese é necessária ao Estado democrático de direito, no qual a condição de ser governista ou de ser oposicionista depende mais da decisão determinada pelo voto da maioria num exercício elementar de cidadania e menos do livre-arbítrio individual. Afinal, nos sistemas de ensino do Estado democrático de direito, não se é governo ou oposição por decisão

Olh@res, Guarulhos, v. 2, n. 1, p. 270-301. Maio, 2014. 
idiossincrática, pelo contrário, se é o que se deve ser por decisão democrática. Essa é uma aprendizagem necessária de todos os professores e professoras, gestoras e gestores, alunos e alunas e de quem com todos eles e elas aprende a pesquisar.

\section{Conclusão: A formação continuada tem fome de quê?}

Parece que precisaremos concluir nos colocando diante de uma contradição inédita e viável como diria Freire, ou de uma desequilibração de Piaget, ou em uma zona de desenvolvimento proximal como interpretaria Vygotsky. Parece necessário conciliar a ousadia da pesquisa no campo da educação popular com a sobriedade da gestão de um sistema de ensino sob um governo popular. Afinal, os sistemas de ensino, ainda mais nas suas etapas iniciais, se sustentam sobre uma única razão democrática e pedagógica: o direito de cada criança realizar seu desejo de aprender! Esse desejo fundamenta tanto a proposta da autora que atua na gestão, quanto à aposta de quem atua na pesquisa. $\mathrm{O}$ fato de as crianças desejarem aprender representa a síntese dialética entre a capacidade técnica e a capacidade emocional, uma opondo-se à outra, no esforço dialético de assegurar as melhores condições de aprendizagem para crianças no seu processo de alfabetização, objeto e objetivo deste projeto de formação. Essa é a razão tanto do conhecimento técnico-político quanto do conhecimento teórico-acadêmico. É o que tentaremos ensaiar a seguir em rápida avaliação pessoal de educadores em meio ao processo do qual somos partícipes, uma autora na condição de gestora, o outro na de pesquisador e outra ainda na coordenação da pesquisa.

A profisssão docente se fundamenta no conhecimento científico, razão pela qual "a formação de docentes para atuar na educação básica far-se-á em nível superior" (LDB, art. 62). O exercício profissional do Magistério, no entanto, além de necessitar da competência científica, requer certo nível de idealismo. Os professores são idealistas quando realizam a melhor educação de que são capazes para cada criança de suas salas de aula e, com frequência, se frustram ao olhar nos olhos da criança que não conseguiu aprender, apesar do seu próprio esforço e do esforço de seu docente. Pessoas idealistas sofrem, mas não perdem a sensibilidade diante das injustiças que assolam a vida de tantas crianças e adolescentes em suas salas de aula. Objetivamente, a democracia e o estado de direito carecem de

Olh@res, Guarulhos, v. 2, n. 1, p. 270-301. Maio, 2014. 
idealistas que mantenham acesa a utopia democrática da ciência pedagógica de que todos e todas são capazes de aprender a aprender.

Em 18 de junho de 1993, no Rio de Janeiro, no lançamento da Ação da Cidadania contra a Fome, a Miséria e pela Vida, Herbert de Souza, o saudoso Betinho, encarnou o ideal democrático brasileiro ao gritar para o país: "a fome não pode esperar". Dez anos depois, em $1^{\text {o }}$ de junho de 2003, em Evian na França, na Cúpula do G-8, outro idealista, Luiz Inácio Lula da Silva, repetiu: “A fome não pode esperar. É preciso enfrentá-la com medidas emergenciais e estruturais" (BRASIL, 2008, p. 19). Betinho e Lula, cada um de seu modo e do seu jeito, sensibilizaram a cidadania! Não acabaram com a fome, mas compartilharam um ideal com milhões de pessoas e, ao partilhá-lo, acabaram com a fome de muitos que não podiam esperar.

A formação continuada de docentes não acabará com a fome de conhecimento que existe em cada criança que não aprende. O idealismo dos docentes, por mais qualificada que seja sua prática, não acabará com a fome de saber. Talvez seja importante que a formação permanente dos docentes capacite-os para a partilha do ideal democrático e pedagógico: todas as crianças são capazes de aprender. Ao partilharem deste ideal, os docentes diminuirão a fome de conhecimento de cada criança com o único alimento capaz de saciá-la: o desejo de aprender. Talvez, no insaciável desejo de aprender da criança, o Magistério encontre sua razão e sua emoção de ser educador e educadora.

Olh@res, Guarulhos, v. 2, n. 1, p. 270-301. Maio, 2014. 


\section{Referências}

ALARCÃO, I. Formação reflexiva de professores. Porto: Porto Editora, 1996.

Formar-se para formar. Revista Aprender, Aveiro, n. 15, p. 19-25, 1993.

BIANCHETTI, L.; RISTOFF, D. A Pós-Graduação e suas interlocuções com a Educação Básica: (Des)encontros históricos e manutenção do apartheid socioeducacional. In: RAMOS, F. B.; PAVIANI, N. M. S.; AZEVEDO, T. M. de. (Org.). A pós-graduação e suas interlocuções com a educação básica: múltiplos olhares. Caxias do Sul/RS: EDUCS, 2012, p. 178-241.

BRASIL. Ministério da Educação. Coordenação de Aperfeiçoamento de Pessoal de Nível Superior. Plano Nacional de Pós-Graduação - PNPG 2011-2020. Brasília: CAPES, 2010. Disponível em: http://www.capes.gov.br/images/stories/download/Livros-PNPG-Volume-I-Mont.pdf, acesso em 24.10.2012.

BRASIL. Discursos selecionados do Presidente Luiz Inácio Lula da Silva. Brasília: Fundação Alexandre de Gusmão, Ministério das Relações Exteriores, 2008. Disponível em: http://funag.gov.br/biblioteca/index.php?option=com_docman\&task=doc_download\&gid=144\&Ite

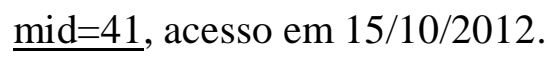

CANOAS, Prefeitura Municipal. Informativo Municipal da Prefeitura de Canoas, Canoas, v. 3, n. 27, jul./2011. Disponível em: http://www.canoas.rs.gov.br/uploads/midia/5500/jornal_de_canoas_julho_2011.pdf, acesso em $15 / 10 / 2012$.

CANOAS, Prefeitura Municipal. Plano de Cargos, de Carreira e de Remuneração do Profissional do Magistério do Município de Canoas, Lei no 5.580 de 11/02/2011. Disponível em: http://www.leismunicipais.com.br/cgi-local/form_vig.pl, acesso em 15/10/2012.

DEVECHI, C. P. V.; TREVISAN, A. L. Abordagens na formação de professores: uma reconstrução aproximativa do campo conceitual. Revista Brasileira de Educação, Rio de Janeiro, v. 16, n. 47, p. 409-416, mai./ago. 2011.

DUBET, F. Quando o sociólogo quer saber o que é ser professor. Revista Brasileira de Educação, Rio de Janeiro, n. 5 e n. 6, p. 222-231, jan./dez. 1997.

FREIRE, P. Política e educação: ensaios. 5. ed. São Paulo: Cortez, 2001.

GATTI, B. A. Análise das políticas públicas para formação continuada no Brasil, na última década. Revista Brasileira de Educação, Rio de Janeiro, v. 13, n. 37, p. 57-70, jan./abr. 2008

Olh@res, Guarulhos, v. 2, n. 1, p. 270-301. Maio, 2014. 
GLEWWE, P.; KASSOUF, A. L. The Impact of the Bolsa Escola/Familia Conditional Cash Transfer Program on Enrollment, Drop Out Rates and Grade Promotion in Brazil. Journal of Development Economics, v. 97, p. 505-517, 2012

IBGE - Instituto Brasileiro de Geografia e Estatística. PNAD: Pesquisa Nacional por Amostra de Domicílios. Síntese de indicadores. 2011. Rio de Janeiro: IBGE, 2012. Disponível em: ftp://ftp.ibge.gov.br/Trabalho_e_Rendimento/Pesquisa_Nacional_por_Amostra_de_Domicilios_anu al/2011/Sintese_Indicadores/sintese_pnad2011.pdf, acesso em 15/10/2012.

IPEA - Instituto de Pesquisas Econômicas Aplicadas. Gastos com a Política Social: Alavanca para o crescimento com distribuição de renda. Comunicados do IPEA, Brasília, n. 75, 03 de fevereiro de 2011.

Disponível

em:

http://www.ipea.gov.br/portal/images/stories/PDFs/comunicado/110203_comunicadoipea75.pdf, acesso em 15/10/2012.

MOITA, F. M. G. da S. C.; ANDRADE, F. C. B. de. Ensino-pesquisa-extensão: um exercício de indissociabilidade na pós-graduação. Revista Brasileira de Educação, Rio de Janeiro, v. 14, no 41, p. 269-280, mai./ago. 2009.

NÓVOA, A. Formação de professores e profissão docente. In: . (org.). Os professores e sua formação. Lisboa: Porto Editora, 1992. p. 11-33.

OEI. Organización de Estados Iberoamericanos para la Educación, la Ciencia y la Cultura. 2012: Miradas sobre la educación en Iberoamérica. OEI: Madrid, 2012. Disponível em: http://www.oei.es/miradas2012.pdf, acesso em 15/10/2012.

PARO, Vitor Henrique. Educação como exercício do poder: crítica ao senso comum em educação. São Paulo: Cortez, 2008.

PESSOA, S. de A. Entrevista. Revista Época de 03/09/2012. Resenha Eletrônica do Ministério da Fazenda. Disponível em: http://www.fazenda.gov.br/resenhaeletronica/MostraMateria.asp?page=\&cod=837329, acesso em $15 / 10 / 2012$.

RICCI, R. Lulismo: da Era dos Movimentos Sociais à Ascensão da Nova Classe Média Brasileira. Brasília: Fundação Astrojildo Pereira, 2010.

SAVIANI, D. Formação de professores: aspectos históricos e teóricos do problema no contexto brasileiro. Revista Brasileira de Educação, Rio de Janeiro, v. 14, n. 40, p. 143-155, jan./abr. 2009. SAE. Secretaria de Assuntos Estratégicos. Vozes da Classe Média. Edição: Marco Zero. Brasília, 20 de setembro de $2012 . \quad$ Disponível em http://www.liberdadedeexpressao.inf.br/clientes/sae/cartilha-projeto.pdf, acesso em 15/10/2012.

Olh@res, Guarulhos, v. 2, n. 1, p. 270-301. Maio, 2014. 
Reflexões sobre as políticas públicas na área de formação continuada de professores: a experiência do município de Canoas/RS

SENAI. Serviço Nacional de Aprendizagem Industrial. Mapa da Profissão Industrial 2012. SENAI/MT: Mato Grosso, 20/09/2012. Disponível em: http://www.senaimt.com.br/site/mostra_arquivo.php?arquivo=1037, acesso em 15/10/2012.

SILVA, G. F. da; NÖRNBERG, M.; PACHECO, S. M. Processos formativos a partir de práticas inclusivas na educação básica. Inter-Ação, Goiânia, v. 37, n. 1, p. 91-112, jan./jun. 2012. UNESCO. Organização das Nações Unidas para a Educação, a Ciência e a Cultura. O Perfil dos professores brasileiros: o que fazem, o que pensam, o que almejam. São Paulo : Moderna, 2004 ZEICHNER, K. M. A formação Reflexiva de Professores: idéias e práticas. Lisboa: EDUCA, 1993.

Olh@res, Guarulhos, v. 2, n. 1, p. 270-301. Maio, 2014. 